になっている。即ち試料の伸び $1 \mathrm{~mm}$ が， $25 \mathrm{~mm}, 50$ $\mathrm{mm}, 125 \mathrm{~mm}$ に拆大して記録される。

第 4 図，第5 図，はすべて 25 倍に拡大した記録で ある。試作機の伸びの記録精度は土2/100mm 以内であ った。

\section{5. 試作機の性能；仕様}

荷 重 精 度 $\pm 1.0 \%$

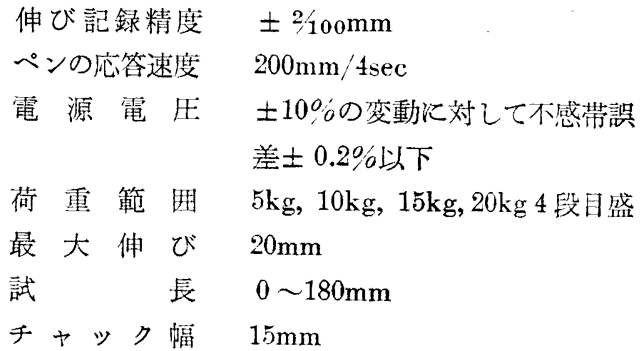

\title{
○当協会講演会
}

下記次第にて講演会を僬し，盛大であった。本講演は来春の本惁愺せる予定である。

1. 演 題と 講 稨

『英国製紙工業に於ける「ブタコン」合成ラテックスの進歩(スライド付)』

講 師 英国インペリアル・ケミカル・インダストリーズ・リミッテッド・プラスチックス・ディヴィジ

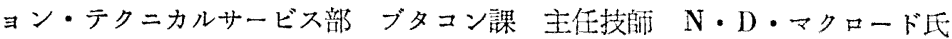

(通訳。付)

1. 日時昭和 34 年 10 月 16 日（金）午後 2 時より約 2 時間

1. 主催紙 パルプ技尃協会

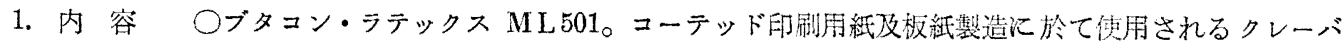
インダー

○ブタュン・ラテックス ML507。紙及板紙製造に於て使用されるトップニーティング

○ブタコン・ラテックス ML508。ビーターアディション及び紙の禽浸荗

○ブタコン・ラテックス A L 911 。紙コーティングの顔料バインダー及び悢の含浸剂

以上

\section{○訂正}

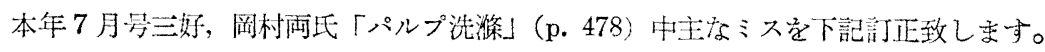

\begin{tabular}{|c|c|c|c|}
\hline & & 䛊 & 正 \\
\hline p. 479 & 下より 1行目 & 円筒につれて & 回転とともに \\
\hline p. 481 & 下より11行日 & 液の压力により & 液の珐力差により \\
\hline p. 482 & 右下数表 & $1.7 \%$ B.D & $17.0^{\circ} ;$ B.D \\
\hline
\end{tabular}

